ФИЛИППОВ АЛЕКСАНДР*

\title{
МЕХАНИЗМ СМЕНЫ ВЛАСТИ В РАННЕБАХРИТСКИЙ ПЕРИОД (1250-1261ГГ.)
}

Мамлюкский период является самой продолжительной эпохой в истории мусульманского Египта. Одной из его главных характеристик является доминирование в политической сфере тюрков, которые, прибывая в Египет в качестве рабов, смогли занять место в высших эшелонах власти. Особый интерес мамлюкский период представляет для изучения трех сорер: а) соотношение этнических и исламских особенностей в мусульманских странах, проблема единства и региональности исламской цивилизации. Л.Р. Полонская справедливо замечает, что с течением времени в ислам включались элементы других цивилизаций', фрормируя, таким образом, уникальность регионов мусульманского мира; б) из этого автоматически вытекает вопрос об адаптивных возможностях ислама, его способности перекодировать или уничтожить специфические черты той или иной культуры; в) и третья сфера касается влияния на исламский мир тюрков, которые доминировали в нем с XI по начало XX вв.

В настоящей статье рассматриваются первые годы правления в Египте мамлюков ал-Бахри, кыпчаков по происхождению. Доминирование тюрков в политической сфере не могло не привести к внедрению тюркских элементов в систему государственного управления. Вместе с тем, имели место и противоположные процессы исламизация и арабизация ${ }^{2}$ новых правителей Египта. В настоящее время исследо-

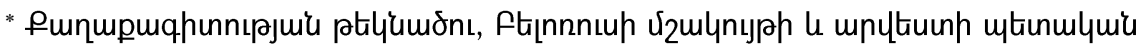
huvumumpuik:

1 Полонская Л. “Единство и многообразие ислама”. Восток (Oriens), 1994, стр. 6.

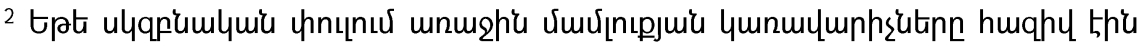

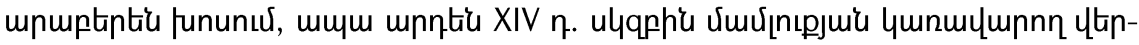

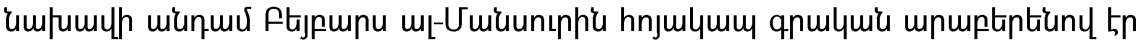


ватели переосмысливают свои представления о мамлюках, как о невежественных варварах, отмечая их огромный вклад в развитие египетской культуры ${ }^{3}$. Разрушение традиционных родоплеменных связей среди оторванных от своей родины мамлюков, которые были вынуждены жить в иноэтничном и инокультурном окружении, вело к размыванию и исчезновению традиционных тюркских социально-политических институтов или же, что бывало гораздо чаще, придавало им исламскую окраску.

В последнее время мамлюкский период все больше и больше привлекает внимание исследователей. Появляются многочисленные монографии 4 , сводные работь ${ }^{5}$, статьи $^{6}$. Однако проблема механизма смены власти практически не затрагивается. На наш взгляд, это связано со следующими обстоятельствами: при изучении тюркских институтов исследователь-арабист вынужден постоянно обращаться за пределы сореры своей компетенции. С другой стороны, исследователю-тюркологу также непросто работать с непрофильным для него арабским материалом. Нет единодушного мнения, что следует понимать под "традиционными тюркскими институтами». Если политическое устройство Тюркских каганатов (VI-VIII вв.), то насколько закономерно игнорировать более чем пятисотлетний разрыв между ними и египетскими мамлюками. Если же за основу брать тюркские государства, которые возникли после VIII в., то и здесь ситуация неочевидна: с

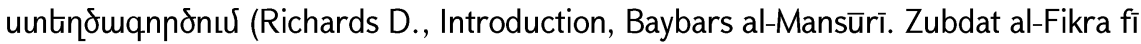
Ta'rīch al-Hijra, Berlin-Beirut, 1998, p. XIX).

3 The Mamluks in Egyptian politics and society, Cambridge, 1998, pp. 163-173.

4 Семенова Л. “Салах ад-Дин и Мамлюки (новые исследования)”. Восток (Oriens), 1993, стр. 194-207.

5 The Mamluks in Egyptian politics and society, Cambridge, 1998, pp. 163-173. A Short History of Turkish-Islamic States (Excluding the Ottoman State), Ankara, 1994. The Turks, in 6 vol., vol. 2, Middle Ages, Ankara, 2002.

6 Tamām A., Qutuz: Qahara al-mugūl wa ța'anahu al-rifāq, 1422 г.х., http://www.islamonline.net/Arabic/history/1422/01/article30.shtml; Кадырбаев А. “Царица Египта Шаджарат ад-Дурр: 1249-1250гг. (Повествование о тюркской рабыне, ставшей императрицей и основательницей государства Мамлюков)”. Египет, Ближний Восток и глобальный мир. Москва, 2006, стр. 108-112. 
одной стороны, в тюркские государства активно проникает ислам и начинается миграция тюрков в районы проживания других народов со всеми вытекающими отсюда последствиями. С другой стороны, у нас далеко не всегда хватает нужной информации, чтобы выстроить экспертную систему хотя бы по одному тюркскому народу. В результате исследователь вынужден иметь дело с очень разнородным материалом, что, безусловно, ставит под сомнение полученные выводы. Третья причина заключается в том, что большинство источников по мамлюкскому периоду созданы арабами или арабизированными тюрками, то есть людьми, которые, описывая происходящие процессы, зачастую игнорировали многие детали как несущественные или непонятные для них и обращали основное внимание на исламские институты. Естественно, что опускались или искажались как раз сведения, касающиеся тюркских элементов в египетском обществе.

При написании данной статьи автор стремился установить механизм смены власти, которому следовала правящая элита в раннебахритский период. Хронологические рамки работы охватывают эпоху от свержения аййубидского султана ал-Муаззама Туран-шаха до восстановления Аббасидского халифата в Египте. Такой выбор обусловлен тем, что после прихода мамлюков к власти и до провозглашения Халифата новые правители Египта не имели возможности задействовать исламский механизм легитимации власти - санкцию халифа. Таким образом, именно в это время на официальном уровне должна была использоваться другая традиция смены власти. После восстановления Халифата внешне султаны начинают следовать исламским правилам передачи власти, то есть акцент делается на получении таклида от халифа. Несмотря на краткость заявленного периода, он может считаться в достаточной степени репрезентативным для решения поставленной задачи - за 11 лет сменилось 6 правителей: Шаджарат ад-Дурр (1250г.), ал-Ашраф Муса (1250-1252гг.), ал-Муизз Изз ад-Дин Айбек (12501257гг., до 1252 г. - соправитель ал-Ашрафа), ал-Мансур Нур ад-Дин Али (1257-1259гг.), ал-Мудзаффрар Сайф ад-Дин Кутуз (1259-1260гг.) и аз-Захир Рукн ад-Дин Бейбарс (1260-1277гг.).

Под «традиционными тюркскими институтами» автор понимает такие институты, которые фиксируются у максимально большого чис- 
ла тюркских народов с обязательным рассмотрением доисламской тюркской традиции, которые не имеют параллелей в истории других арабских стран, название которых представляют собой фонетическую или семантическую кальку с тюркских языков; и, наконец, вызывающие негативную реакцию со стороны исламских кругов.

Основным источником для написания настоящей работы является фрагмент произведения раннемамлюкского периода “Сливки мысли в истории хиджры” (Zubdat al-Fikra fi Ta’rīch al-Hijra), охватывающий период до 659 г.х. (1261 г.). Эта хроника была написана в начале XIV века одним из представителей мамлюкской элиты, заместителем султана (nā'ib al-sulțān) в 1311-1312 гг., Бейбарсом ал-Мансури ан-Насири (ум. 1325 г.) $)^{7}$. Источник впервые опубликован в 1998 г. в Берлине и в Бейруте на арабском языке, на русский язык не переводился. Хроника Бейбарса аль-Мансури - единственный известный источник, написанный представителем высшей мамлюкской элиты, который, помимо всего прочего, лично участвовал во многих описываемых им событиях, что делает его более надежным по сравнению с трудами последующих авторов. Также при написании статьи широко использовались труд известного мамлюкского историка Ахмада Ибн Али ал-Макризи (1364 1422гг.) «Kitāb al-Sulūk li-ma'rifat duwal al-mulūk» за соответствующие годы и произведение Ибн Тагриберди (1409-1470гг.) «Al-Nujūm al-zāhira fi mulūk Mişr wa al-Qāhira». Bce переводы дат из летоисчисления от хиджры в летоисчисление от рождества Христова сделаны по таблице Х.К. Баранова ${ }^{8}$.

Для определения ключевых элементов механизма смены власти необходимо кратко рассмотреть каждую смену правителя в мамлюкском Египте в указанный период. Первой мамлюкской правительницей традиционно считается Шаджарат ад-Дурр 9 . Арабские источники также

${ }^{7}$ Richards D., 'u24. m2łu., $t_{2}$ XVIII:

${ }^{8}$ Баранов X., Таблица согласования годов хиджры с годами христианской эры, Арабско-русский словарь, т. 2, Москва, 2002, стр. 924-926.

9 Лэн-Пуль С. “Мусульманские династии”. Москва, 2004, стр. 61. Учок Б. “Женщины-правительницы в мусульманских государствах”. Москва, 1982, стр. 44; Босворт К. "Мусульманские династии”. Справочник по хронологии и генеалогии, Москва, 1971, стр. 99. 
называют эту женщину правительницей, ставя рядом с ней слово «султан»: «но недолго длилось ее качество (simat $\left.{ }^{4}\right)$ как султана» ${ }^{10}$; «и получила она султанскую власть» ${ }^{11}$. Ибн Тагрибирди лишь кратко упоминает о том, что Шаджарат ад-Дурр правила (malakat) после Тураншаха ${ }^{12}$. Правление вдовы ас-Салиха Наджм ад-Дина (правил в 12401249гг.) можно охарактеризовать следующими особенностями:

1. Возведение на престол женщины, что вызвало негативную реакцию со стороны халифра, написавшего резкое письмо, в котором говорилось: «Если у вас закончились мужчины, то сообщите мне, и я пришлю вам кого-нибудь» ${ }^{13}$, а также привело к фрактическому отделению сирийских владений Аййубидов и к выступлению местных правителей против Египта ${ }^{14}$.

2. Провозглашение новой правительницы, столь сильно осложнившей внешнеполитическое положение Египта, произошло в ходе отражения VII Крестового похода ${ }^{15}$. Интересно, что в дальнейшем именно физическая неспособность государя возглавить войско стала одним из поводов возведения на престол нового монарха ${ }^{16}$.

3. Очень краткий период правления Шаджарат ад-Дурр - около 3 месяцев ${ }^{17}$.

Все вышесказанное позволяет предположить, что возведение Шаджарат ад-Дурр на престол было вынужденным шагам, на который мамлюкские эмиры, тем не менее, пошли. Несмотря на переосмысление в современной историографии положения слабого пола в

${ }^{10}$ Baybars al-Mansūrī, Zubdat al-Fikra fí Ta'rīch al-Hijra, Berlin-Beirut, 1998, ţ2 3: 11 al-Maqrīzì Ahmad ibn 'Alī, Kitāb al-Sulūk li-ma'rifat duwal al-mulūk, 648 p., http://www.al-eman.com/islamlib

12 Ibn Taghrïbirdī, Al-Nujūm al-zāhira fî mulūk Mişr wa al-Qāhira, Aybek, http://www.al-eman.com/islamlib

${ }^{13}$ al-Maqrīīi, 648 p.:

${ }^{14}$ al-Maqrīīi, 648 p.: Ibn Taghrïbirdī, Aybek. Baybars al-Mansūrī, ť 3-4:

${ }^{15}$ Strayer J., The Crusades of Louis IX, A History of the Crusades. Volume Two. The Later Crusades 1189-1311, Madison, 1969, p. 499. al-Maqrīīi, 648 p.:

${ }^{16}$ Baybars al-Mansūrī, $t_{2}$ 6, 46:

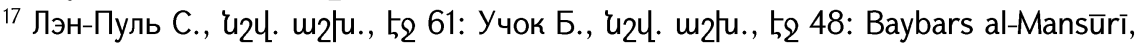
стр. 3. al-Maqrīzī, 648 p.: Ibn Taghrïbirdī, Aybek. 
исламском обществе ${ }^{18}$, восшествие на престол женщины было беспрецедентным случаем. Тот факт, что вдова ас-Салиха была выдана замуж за назначенного эмирами атабеком войска Изз ад-Дина Айбека ат-Туркмани ${ }^{19}$, который помимо этого стал соправителем малолетнего аййубидского малика ал-Ашрафа Мусы $^{20}$, позволяет предположить, что все мероприятие с Шаджарат ад-Дурр и было затеяно с целью расчистить путь к высшей власти для безродного мамлюкского предводителя. Эта мысль подтверждается и тем, что, как правило, жены мамлюкских правителей не участвовали в политической и общественной жизни ${ }^{21}$. То обстоятельство, что подобный шаг был отвергнут и Аййубидами, и халифом, санкции которого на произведенный ими переворот мамлюкские правители упорно добивались вплоть до 1261г.22, дает основание считать, что возведение на трон вдовы аййубидского малика Салиха Наджм ад-Дина имело значение исключительно для мамлюкских эмиров и не играло никакой положительной роли в глазах халифра и Аййубидов.

В свете всего изложенного необходимо рассмотреть имеющиеся данные по положению женщин в правящей элите в традиционной тюркской политической системе. Р.С. Липец отмечает, что в тюркскомонгольском эпосе существует устойчивый образ «женщины-добычи» ${ }^{23}$. Что касается брака, то он в эпосе может выступать в трех формах ${ }^{24}$ :

1. Брак с девушкой, полученной героем в результате «нормального» сватовства, что случается достаточно редко.

18 DeLong-Bas N., Wahhabi Islam. From Revival and Reform to Global Jihad, Oxford, 2004, pp. 123-191.

${ }^{19}$ al-Maqrīīi, 648 р.: Baybars al-Mansūrī, 52 24:

${ }^{20}$ al-Maqrīzī, 648 p.: Ibn Taghrïbirdī, Aybek. Baybars al-Mansūrī, $t_{2} 6$ :

${ }^{21}$ The Turks, in 6 vol., vol. 2, Middle Ages, Ankara, 2002, p. 281.

22 Филиппов А. “Становление власти Мамлюков в Египте (1252-1260гг.)". Египет, Ближний Восток и глобальный мир, Москва, 2006, стр. 115.

23 Липец Р. "Завоеванная женщина” в тюрко-монгольском эпосе. "Фольклор и историческая этнография". Москва, 1983, стр. 42.

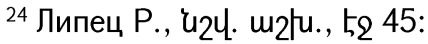


2. Брак с невестой, которую отец вынужден отдать против своей воли, будучи побежденным или устрашенным.

3. Брак с захваченной в походе пленницей.

Исследователь отмечает две важные особенности подобных сою3ов: женитьба героя на жене или дочери своего противника является способом подтверждения его полной победы над своим врагом; муж захваченной женщины автоматически роднится со всем ее родом ${ }^{25}$. Сам брак же зачастую лишь подтверждал доминирующее положение «племени-народа» жениха ${ }^{26}$.

История тюрков также подтверждает, что женщина могла оказаться на самой вершине власти. В Тюркском каганате в каганских семьях женщины иногда допускались к управлению государством ${ }^{27}$. У орхоноенисейских тюрок во время отсутствия мужа управление ордой переходило в руки жены ${ }^{28}$. Характерно, что такая женщина обозначалась в источниках сложным словом «älbilgä», которое Бернштам переводит как «управительница элем» ${ }^{29}$. Только хатун (катун) (qatyn) могла стать «älbilgä». Словом же катун (qātūn) в древнетюркских памятниках называется только жена правителя ${ }^{30}$. Особо интересна история с Теркен-хатун, матерью предпоследнего хорезмшаха Ала ад-Дина Мухаммада (1200-1220гг.) $)^{31}$. Источники единогласны, что Теркен-хатун была из кипчакского рода, но расходятся в вопросе о том, к какому конкретно кипчакскому племени она принадлежала. Согласно Джу-

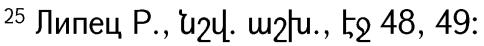

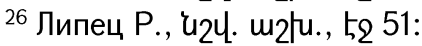

27 Стеблева И. “Жизнь и литература доисламских тюрков”. Москва, 2007, стр. 17.
}

${ }^{28}$ Бернштам А. "Социально-экономический строй орхоно-енисейских тюрок VIVIII веков”. Труды Института Востоковедения АН CCCP. T. XLV, Москва-Ленинград, 1946, стр. 99.

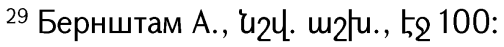

30 Дадабаев X. "Общественно-политическая и социально-экономическая терминология в тюркоязычных письменных памятниках XI-XIV вв.”. Ташкент, 1991, стр. 64.

${ }^{31}$ Шихаб ад-Дин Мухаммад ан-Насави. “Жизнеописание султана Джалал ад-Дина Манкбурны”. Баку, 1973, стр. 84. 
вейни, Теркен-хатун принадлежала к племени кангль ${ }^{32}$. Джузджани сообщает, что она была дочерью кипчакского хана по имени Акран $\left(\right.$ Икран) ${ }^{33}$. Шихаб ад-Дин Мухаммад ан-Насави, личный секретарь последнего хорезмшаха Джалал ад-Дина и автор его биографии, написанной в жанре «сира», «Жизнеописание султана Джалал ад-Дина Манкбурны» сообщает, что Теркен-хатун происходила из племени баят, которое является ветвью племени емек ${ }^{34}$.

К сожалению, каких-либо сведений о племени емек нам собрать не удалось. Рашид ад-Дин ни разу не упоминает такого племени в своем "Сборнике летописей». Существовало кипчакское племя йемек, но оно, как и племя канглы, принадлежало к числу кочевых племен, летовки которых располагались на склонах гор, которые китайцы называли Юйлиболи (вероятно, южные склоны Уральских гор) ${ }^{35}$. В конце XII века йемеков упоминают русские летописи под именем половцев Емекове в районе реки Камьі ${ }^{36}$.

Племя баят также не упоминается Рашид ад-Дином, если только не имеется в виду племя «баяут», которое последний относит к «тюрским племенам, прозвание которых было монголы» ${ }^{37}$. Это противоречило бы словам Шихаб ад-Дина Насави, который сообщает, что «она была дочерью хана Джанкиши, одного из тюркских государей ${ }^{38}$. Авторы "Истории Казахской ССР» считают, что Теркен-хатун (Туркан-хатун) происходила из кипчакского племени уран ${ }^{39}$. Переводчик «Жизнеописания султана Джалал ад-Дина Манкбурны», З.М. Буниятов, хотя и пишет в переводе «Теркен-хатун была из племени Баят, а это одна из

32 Буниятов 3. "Комментарии, Шихаб ад-Дин Мухаммад ан-Насави. Жизнеописание султана Джалал ад-Дина Манкбурны”. Баку, 1973, стр. 326.

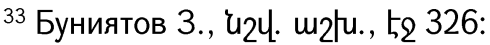

34 Шихаб ад-Дин Мухаммад ан-Насави, 'u24. ш2łu., $5_{2} 87$ :

35 Ахинжанов С.. “Кипчаки и Хорезм в канун монгольского нашествия”. Вестник АН Казахской ССР, 1970, 1 (297), Алма-Ата, стр. 48.

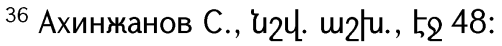

37 Рашид ад-Дин. “Сборник летописей”, т. 1, ч. 2, Москва, 2002, стр. 175-177.

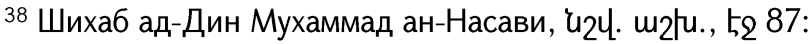

39 История Казахской ССР с древнейших времен до наших дней. Т. 2, АлмаАта, 1979, стр. 54. 
ветвей [племени] Емек» ${ }^{40}$, в своем исследовании, посвященном государству Хорезмшахов-Ануштегинидов, указывает, что Теркенхатун была из племени уран ${ }^{41}$. Таким образом, хотя нужно с оговоркой говорить о том, из какого конкретного племени происходила Теркенхатун, все источники указывают на ее тюркское происхождение.

По сообщению того же Шихаб ад-Дина, Таксин, «сын Ил-Арслана, женился на ней, как женятся государи на дочерях государей. Когда власть перешла к султану Мухаммаду по наследству от его отца Таксина, к нему примкнули племена Емек и соседние с ними. Благодаря им умножились силы [султана], и он возвысил их положение. По этой причине Теркен-хатун и хозяйничала в государстве, а как только султан захватывал какую-либо страну, обязательно выделял для ее приближенных важную область» ${ }^{42}$.

Теркен-хатун обладала огромной властью в государстве. По существу, она была независимой владычицей Хорезма, где находились жены и дети султана, а также заложники ${ }^{43}$. Многие области государства Хорезмшахов подчинялись непосредственно Теркен-хатун. Более того, она приняла лакаб на персидском языке «властительница мира khodāwand-e jahān» и свою личную тугру на арабском языке для указов: «Защитница мира и веры Великая Теркен, владычица женщин обоих миров - 'işma(t) al-dunyā wa al-dīn улуг (тюркское слово uluү) Теркен malika(t) insā' al-'ālamayn»" ${ }^{44}$. По сообщению аль-Макризи похожим титулом была наделена некоторыми хатибами и Шаджарат ад-Дурр: 'işma(t) al-dunyā wa al-dīn, malika(t) al-muslimīn, umm al-Khalīl - защитница мира и веры, правительница мусульман, мать ал-Халила» ${ }^{45}$. Между Теркен-хатун и Шаджарат ад-Дурр можно провести еще одну очень интересную параллель: египетская правительница, придя в ярость от

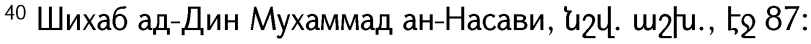

41 Буниятов 3.. “Государство Хорезмшахов-Ануштегинидов”. 1097-1231, Москва, 1986, стр. 147.

42 Шихаб ад-Дин Мухаммад ан-Насави, 'u24. шұһu., 52 87:

43 Шихаб ад-Дин Мухаммад ан-Насави, 'u24. шұłu., 5,283 :

44 Буниятов 3. “Государство Хорезмшахов-Ануштегинидов”. 1097-1231, стр. 128; Шихаб ад-Дин Мухаммад ан-Насави, 'и24. шұłu., t2 87:

45 al-Maqrīzī, 648 p.:
} 
стремления Изз ад-Дина Айбека жениться на дочерях правителей Хамы и Мосула, заманила его в баню, где он был убит слугами своей супруги ${ }^{46}$. В отношении же Теркен-хатун рассказывается, что она также пришла в ярость из-за того, что ее муж, султан Текиш (1172-1200гг.), проводил время в бассейне, купаясь с невольницами, и однажды заперла дверь бассейна. Текиш едва не задохнулся (по-видимому, здесь тоже имеется в виду баня - "хаммам» - А.Ф.) от жары, и только вмешательство придворных спасло хорезмшаха от гибели ${ }^{47}$.

Таким образом, можно сделать следующие выводы:

1. История тюрских народов, в том числе и в исламских странах, имеет прецеденты женщин-правительниц ${ }^{48}$, что позволяет предполагать о наличии некой идеальной модели восшествия на престол женщин и их посреднической роли в переходе власти от одного рода к другому.

2. Возведение Шаджарат ад-Дурр в глазах мамлюкских эмиров оправдывало отказ передать власть после свержения ал-Муаззама Туран-шаха его аййубидским родственникам. В соответствии с традиционными тюрскими представлениями катун (qātūn), жена правителя ${ }^{49}$ имела право в его отсутствие стать правительницей государства,

3. Брак на жене покойного правителя служил механизмом для вхождения ее нового мужа в род умершего.

4. Женитьба на такой вдове воспринималось как своеобразное «завоевание» женщины-правительницы, а значит, и подвластных ей территорий.

Однако новая правительница оказалась в очень сложных внешнеполитических условиях: она не могла рассчитывать на поддержку со стороны халифа, то есть на исламскую легитимацию своей власти, а ее воцарение привело к захвату Дамаска ан-Насиром Салах ад-Дином Йусуфом из дома Аййубидов. Ал-Макризи прямо пишет, что опасность со стороны последнего привела к тому, что Шаджарат ад-Дурр

\footnotetext{
${ }^{46}$ Baybars al-Mansūrī, $t_{2} 24:$

${ }^{47}$ Буниятов 3., 'u24. u2/u., $5_{2}$ 62:

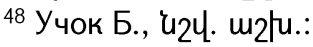

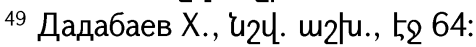


отреклась от престола ${ }^{50}$. На престол был возведен малолетний сын анНасира ал-Ашраф Муса ${ }^{51}$. Этим ходом мамлюки реализовали три цели: связывали руки новому правителю Дамаска, фактически удерживая его сына в почетных заложниках и отвергая любые обвинения в совершении переворота; получали возможность нормализовать отношения с Халифатом; обеспечивали сосредоточение всей полноты власти в руках Изз ад-Дина Айбека. И ал-Макризи, и Ибн Тагриберди подчеркивают вынужденность возведения на трон ал-Ашрафа, отмечая необходимость хоть как-то сдержать Аййубидов ${ }^{52}$.

Сам Айбек был объявлен атабеком при малолетнем правителе ${ }^{53}$.

K XIII веку в тюркско-исламской политической традиции институт атабека уже сложился как один из ключевых элементов механизма узурпации верховной власти.

Термин «атабек» впервые засвидетельствован в форме «ата», или «аты» в орхонских эпиграфических памятниках первой половины VIII века. С помощью этого термина обозначался опекун или воспитатель орхонских принцев. Эту должность всегда занимал только очень знатный тюрок ${ }^{54}$.

После VIII века этот термин исчезает из исторических источников, чтобы возродиться во второй половине XI века в форме «атабек», т.е. «князь-отец". Первое достоверное упоминание термина "атабек» в Сельджукскую эпоху было использовано относительно автора знаменитого произведения “Сиасет-намэ», Низам ал-Мулька, который был атабеком сельджукских султанов Алп-Арслана (1063-1072гг.) и Маликшаха (1072-1093гг.) $)^{55}$.

Применительно к Низам аль-Мульку термин «атабек» можно интерпретировать как «воспитатель, блюститель государственного порядка».

\footnotetext{
${ }^{50}$ al-Maqrīzī, 648 p.:

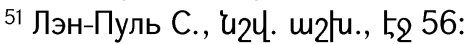

52 al-Maqrīzī, 648 p.: Ibn Taghrībirdī, Aybek.

${ }^{53}$ al-Maqrīzī, 648 p.: Ibn Taghrïbirdī, Aybek. Baybars al-Mansūrī, ${ }_{2}$ 6:

54 Гусейнов Р. “Институт атабеков, Палестинский сборник”. 1966, 15 (78), Москва-Ленинград, стр. 182.

55 Сиасет-намэ. “Книга о правлении вазира XI столетия Низам ал-Мулька”. Москва-Ленинград, 1949, стр. 242.
} 
Низам аль-Мульк не представяет собой типичный образец атабеков, так как впоследствие на эту должность никогда не назначали везирей и нетюрков ${ }^{56}$.

Со времени Мелик-шаха каждый сельджукский принц, в том числе и наследник престола, получал атабека, с которым он не расставался всю свою жизнь ${ }^{57}$. Очень быстро роль атабека в государстве росла. Первоначально, атабеком назывался непосредственный воспитатель принца, но через небольшой промежуток времени атабек стал ответственным за воспитание принца, вставая, таким образом, во главе специального административного аппарата ${ }^{58}$.

Ко времени падения дома Великих Сельджуков в середине XII века, атабеки обладали огромной властью, превратившись в своеобразных «майордомами» при «ленивых» султанах, и, по существу, являлись истинными правителями возникших при развале Сельджукской империи государств ${ }^{59}$. Атабеки стремились быть старшими родственниками правящих султанов. Эта тенденция стала особо отчетливой в XII веке при доминировании атабеков из рода Илдегизидов. Основатель Илдегизидского государства (1136-1225гг.) - Шамс ад-Дин Ил-Дениз (11361175гг.) был женат на Му'амине-Хатун, вдове сельджукского иракского султана Тогрула II $^{60}$ и матери Арслан-шаха (1161-1176гг.). Таким образом, Ил-Дениз приходился последнему не только «князем-отцом», но и дядей через его мать и свою жену ${ }^{61}$, то есть, в соответствии с тюркской системой родства, был «старшим родичем» ${ }^{62}$. Преемник Ил-

${ }^{56}$ Гусейнов Р., 'и2Ч. шұһu., $5_{2} 183:$

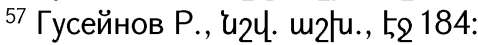

58 Unıju untinnux:

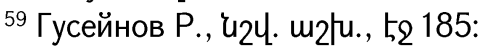

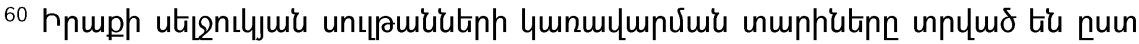
2. Fniupjupnulh шұłuminnıرјu'u (unt'u Буниятов 3., Государство атабеков Азербайджана (1136-1225 годы), Баку, 1978, стр. 237). У Лэн-Пуля - Тогрул I (unt'u Лэн-Пуль С., Мусульманские династии, Москва, 2004, стр. 110, 114).

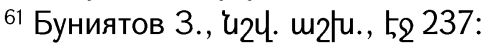

62 Бернштам А. "Социально-экономический строй орхоно-енисейских тюрок VIVIII веков”. Труды Института Востоковедения АН CCCP, т. XLV, Москва-Ленинград, 1946, стр. 91. 
Дениза - Джахан-Пахлаван (1175-1186гг.) (сын Му’амин-Хатун) также сохранил свое старшинство, отравив своего двоюродного брата Арслан-шаха и возведя на престол своего двоюродного племяннника 7-летнего Тогрула III63.

Важно отметить, что атабеком мог быть только тюрок, причем, как правило, незнатного происхождения, выходец из султанских гулямов ${ }^{64}$.

Таким образом, институт атабека фактически являлся одним из ключевых элементов вхождения в правящий род и перехода реальной власти под контроль не связанной с родовыми структурами профессиональной армии. Сделавшись «князем-отцом» ал-Ашрафа, Изз адДин Айбек породнился с Аййубидами, стал старшим родственником малолетнего правителя. Кроме того, он получил право претендовать на египетский трон.

По-видимому, первоначально атабек собирался следовать сельджукской традиции и оставаться реальным, но не номинальным правителем. Казалось бы, это должно было остановить ан-Насира. Однако сирийский малик спутал египетскому правителю все карты, выступив в поход и захватив Газу ${ }^{65}$. Бейбарс ал-Мансури также упоминает об этом походе, однако порядок изложения материала, выбранный автором, не позволяет однозначно установить хронологический порядок событий выступление ан-Насира и свержение ал-Ашрафра ${ }^{66}$. Ал-Макризи и Бейбарс ал-Мансури утверждают, что только вмешательство халифа остановило войска сирийского малика ${ }^{67}$. Ибн Тагриберди же рассказывает о полной победе египтян ${ }^{68}$. По-видимому, можно утверждать, что поход ан-Насира убедил мамлюкских эмиров в бесперспективности

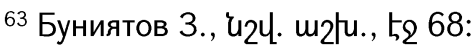

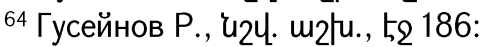

${ }^{65}$ al-Maqrīzī Ahmad ibn 'Alī, Kitāb al-Sulūk li-ma'rifat duwal al-mulūk, mode of access: http://www.al-eman.com/islamlib, 650 p.:

${ }^{66}$ Baybars al-Mansūrī, Zubdat al-Fikra fì Ta'rīch al-Hijra, Berlin-Beirut, 1998, $t_{2} 6$ : 67 al-Maqrīzī Ahmad ibn 'Alī, Kitāb al-Sulūk li-ma'rifat duwal al-mulūk, mode of access: http://www.al-eman.com/islamlib, 650 p.: Baybars al-Mansūrī, Zubdat alFikra fï Ta'rīch al-Hijra, Berlin-Beirut, 1998, $t_{2} 6$ :

${ }^{68}$ Ibn Taghrībirdī. Al-Nujūm al-zāhira fĩ mulūk Mişr wa al-Qāhira, mode of access: http://www.al-eman.com/islamlib, Aybek. 
и дальше сохранять номинальную верховную власть в руках алАшрафра. В 650 г.х. ${ }^{69}$ (1250г.) совет эмиров принял решение о единовластии малика ал-Муизза Изз ад-Дина Айбека, окончательно свергнув династию Аййубидов ${ }^{70}$. Формальным поводом для лишения власти малолетнего малика послужило начало монгольского похода под командованием Хулагу и неспособность ребенка возглавить войско ${ }^{71}$. Ибн Тагриберди же указывает другую причину: поддержка ан-Насиром основного противника Айбека внутри Египта - Фарис ад-Дина Актая и препятствование браку атабека с дочерью правителя Хамьі ${ }^{72}$.

Таким образом, Изз ад-Дин Айбек, женатый на вдове малика асСалиха Наджм ад-Дина и бывшей правительнице Египта Шаджарат адДурр, будучи атабеком - «князем-отцом» малолетнего ал-Ашрафа с точки зрения тюрских представлений был породнен с Аййубидами и имел формальные права на трон.

Однако при воцарении нового малика был задействован еще один третий - элемент механизма смены власти. Все источники единогласны, что при восшествии Айбека на трон, как и в случае с Шаджарат адДурр, было получено «согласие эмиров» ${ }^{73}$. Фраза «ittafaqa al-'umarā' -

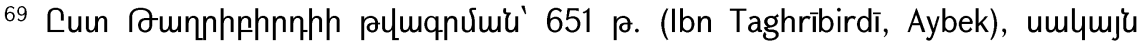

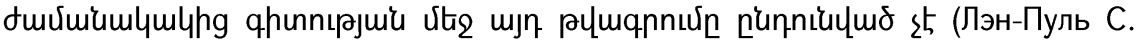
“Мусульманские династии”, стр. 61; Босворт К. "Мусульманские династии", стр. 94. Фильштинский И. М. “История арабов и Халифата 750-1517гг.”. Москва, 2001, стр. 263).

${ }^{70}$ Baybars al-Mansūrī, Zubdat al-Fikra fĩ Ta'rīch al-Hijra, Berlin-Beirut, 1998, c. 6; al-Maqrīzī Ahmad ibn 'Alī, Kitāb al-Sulūk li-ma'rifat duwal al-mulūk, mode of access: http://www.al-eman.com/islamlib, год 650; Ibn Taghrībirdī. Al-Nujūm alzāhira fī mulūk Mişr wa al-Qāhira, mode of access: http://www.aleman.com/islamlib, Aybek.

${ }^{71}$ Baybars al-Mansūrī, Zubdat al-Fikra fī Ta'rīch al-Hijra, Berlin-Beirut, 1998, $t_{2}$ 6: al-Maqrīzī Ahmad ibn 'Alī, Kitāb al-Sulūk li-ma'rifat duwal al-mulūk, mode of access: http://www.al-eman.com/islamlib, 650 p.:

72 Ibn Taghrībirdī. Al-Nujūm al-zāhira fĩ mulūk Mişr wa al-Qāhira, mode of access: http://www.al-eman.com/islamlib, Aybek.

${ }^{73}$ Baybars al-Mansūrī, Zubdat al-Fikra fì Ta'rīch al-Hijra, Berlin-Beirut, 1998, t, 6: al-Maqrīzī Ahmad ibn 'Alī, Kitāb al-Sulūk li-ma'rifat duwal al-mulūk, mode of access: http://www.al-eman.com/islamlib, 650 p.: Ibn Taghrïbirdī. Al-Nujūm al- 
(إتفق الأمراء ) встречается в этих источниках достаточно часто, когда речь идет о смене правителя, но только Бейбарс ал-Мансури уточняет, что это были за эмиры, характеризуя их как «старшие эмиры - عارملأار البكا al-'umarā' al-kibār (ед.4. - ريبكلاريملأ - al-'amīr al-kabīr).

Данный институт упоминается за указанный период (1250-1261гг.) в 6 случаях и касается только истории Египта и Румского султаната. Повидимому, он представляет собой элемент тюркско-монгольской политической организации, о чем свидетельствуют следующие факты:

1. "Старший эмир» не упоминается при изложении событий в других мусульманских странах (Ирак, Сирия, Магриб) ${ }^{74}$.

2. В системе традиционной сельджукской политической организации существует институт "больших беков - ولوا رلكب - ūlu bakalar»" дословным переводом этого словосочетания является арабское «аl'umarā' al-kibār». Сам этот инстиут зафиксирован уже в древнетюрской политической системе ulup (ordu, elig) beg (мн.ч. bäglar) ${ }^{76}$.

3. Рашид ад-Дин также неоднократно упоминает «старших (ед.ч. bozorg - بر ب, что в переводе с персидского на арабский дает - kabīr - ريك) эмиров»"77, существование которых в Великой Степи фриксируется до нашествия Чингисхана ${ }^{78}$.

4. Константин Багрянородный (913-959гг.) в своем труде «О6 управлении империей» упоминает о существовании у панчакитов (печенегов) восьми фем, во главе каждой из них стоит «старший ( $\mu \varepsilon ́ \gamma \alpha \varsigma)$ архонт $(\alpha \rho \chi \omega u)^{79}$. Так как ко времени правления императора в Визан-

zāhira fī mulūk Mișr wa al-Qāhira, mode of access: http://www.aleman.com/islamlib, Aybek.

${ }^{74}$ Baybars al-Mansūrī, Zubdat al-Fikra fĩ Ta'rīch al-Hijra, Berlin-Beirut, 1998, ť2 160:

75 Гордлевский В. “Избранные сочинения”, т. 1, Москва, 1960, стр. 116.

76 Древнетюркский словарь. Ленинград, 1969, стр. 610, 170.

77 Рашид ад-Дин. “Сборник летописей”, т. 1-2, Москва, 2002; Рашйд ад-Дйн, Джа̄ми“ ат-тава̄рӣх, т. 1, ч. 1, Москва, 1968, стр. 146, 180, 376, 483 и др.

78 Рашид ад-Дин. “Сборник летописей”, т. 1, Москва, 2002, стр. 272; Рашйд

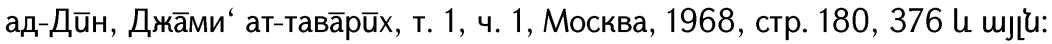

79 Константин Багрянородный. “Об управлении империей”, Москва, 1989, стр. 155-156. 
тии сложилась устойчивая традиция переводить слово «эмир» словом "архонт» ${ }^{80}$, то "старший архонт» в переводе на арабский даст нам - al-'amīr al-kabīr.

Зафиксировав существование «старших эмиров» у многих тюркских народов на протяжении длительного периода времени, мы можем сделать вывод о том, что в данном случае мы имеем дело с элементом традиционной тюркской политической организации.

Традиционное тюркское государственное устройство представляло собой сочетание племенной организации и политической структуры эля (el), которые взаимно дополняли друг друга ${ }^{81}$. Поэтому необходимо выяснить, элементом какого пласта являются «старшие эмиры» родоплеменного или политического, надплеменного.

Характер употребления словосочетания ulup beg (3 примера в статьях "Uluy" и “Elig") в примерах, приводимых Древнетюркским словарем, позволяет предположить, что этот институт был связан с ордой и элем, т.е. являлся элементом политической структуры государства. В государстве Караханидов (992-1211гг.) "улуг беки» неизменно участвовали в ханских советах и были представителями военной, а не родоплеменной знати ${ }^{82}$.

Рашид ад-Дин при характеристике некоторых эмиров употребляет слово "bozorg", которое, как уже упоминалось ранее, семантически практически идентично словам «uluү» и «kabīr» (а также и не́үac). К моменту написания "Сборника летописей» упомянутое слово в персидском языке стабильно использовалась в качестве социального термина. Одним из подразделений Сасанидской аристократии являлись bozorgān ${ }^{83}$, что является множественным числом от слова bozorg. Bozorgān (вар. wuzurgān) отделялись от других четырех подразделений Сасанидской аристократии, в том числе и от āzādegān - «благородных»

80 Бартольд В. “Халиф и султан”. Сочинения в 9 т., т. VІ. Работы по истории ислама и арабского халифата. Москва, 1966, стр. 19.

81 История Востока, в 6 т., т. ІІ. Восток в Средние века. Москва, 2002, стр. 152. 82 Агаджанов С. “Государство Сельджукидов и Средняя Азия в XI-XII веках", Москва, 1991, стр. 68.

${ }^{83}$ Bozorgān, Encyclopaedia Iranica, mode of access: www.iranica.com, p. 427. 
по крови ${ }^{84}$. В фрарси слово ناخداز - āzādegān (ед.ч. آزاز - āzāde) сохранило свое значение «знатного человека» 85 . Характер выбранного Рашид адДином слова позволяет предполагать, что он хотел подчеркнуть неродовое происхождение носившей этот титул знати.

Семантическая калька, выбранная Константином Багрянородным, также недвусмысленно указывает на неродовой характер рассматриваемого нами института. Словом «архонт» император называет правителей государств: арабских халифов, древнерусских князей, южнославянских государей и т.д. ${ }^{86}$. Показательно и название тех территорий, которыми управляют печенежские «архонты» - фемы, т.е. административно-политические подразделения ${ }^{87}$.

Для прагматического анализа мы использовали уже упомянутый труд Рашид ад-Дина, а особенно «Памятку об эмирах туманов и тысяч и о войсках Чингисхана» ${ }^{88}$. Использование этого источника в данном случае нам представляется вполне корректным, так как, как уже отмечалось, Рашид ад-Дин фиксирует существование «старших эмиров» в Великой Степи до начала правления Чингисхана. Проанализировав этот текст, мы пришли к следующим выводам:

1. Титул «старший эмир» никак не связывался с родственниками Чингисхана.

2. «Старшие эмиры» могли назначаться Чингисханом.

3. "Старшие эмиры» возглавляли «тысячи» и "туманы» в войске Чингисхана наравне с эмирами.

4. "Старшие эмиры», будучи тысячниками ${ }^{89}$ в войске Чингисхана, обладали правом назначать эмиров тысячи (sic!) по своему усмотрению ${ }^{90}$.

84 unyju untinnux:

85 Персидско-русский словарь. 1382 (г.х., с.к.), т. 1, Тегеран, стр. 68.

${ }^{86}$ Константин Багрянородный. “Об управлении империей”. Москва, 1989, стр. 51, 71, 73, 113, 161.

87 Константин Багрянородный. “Об управлении империей”, $5_{2}$ 155:

88 Рашид ад-Дин. “Сборник летописей”, т. 1, ч. 2, Москва, 2002, стр. 266-281.

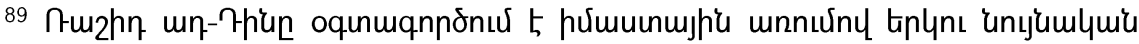
untinúhu. ämīr-e häzāre и ämīr-e häzārī (Рашйд ад-Дйн, 1968, стр. 145, 260).

90 Рашид ад-Дин. “Сборник летописей”, т. 1, Москва, 2002, стр. 272. 
Из всего вышесказанного можно сделать вывод, что «старшие эмиры» назначались в качестве глав надродовых объединений, то есть представляли собой надплеменной институт тюркской государственности.

Далее необходимо попытаться определить роль «старших эмиров» в системе управления мамлюкского Египта. Можно выделить следующие случаи упоминания данного института в фрагменте из "Сливок мысли в истории хиджры” за указанные годы (1250-1261гг.):

1. Аййубиды закупали мамлюков, чтобы «сделать из них старших эмиров и предводителей войска» ${ }^{91}$.

2. Совещание султана Гийас ад-Дина и малика Кутуза со своими старшими эмирами перед решающим сражением с монголами (в первом случае перед битвой при Кусэдаге ${ }^{92}$, во втором случае перед битвой при Айн Джалуте (начало 1260г.) (33. $^{3}$.

3. Упоминание отца и деда («старшие эмиры») и титула (ع бакаларбаки, или бейлербей $)^{94}$ Сайфр ад-Дина Турунтая, сопровождавшего султана Ала ад-Дина Кай-Кубада к Менгу, а после смерти султана ставшего послом султана Изз ад-Дина Кай-Кавуса ${ }^{95}$. Случай с Сайф адДином Турунтаем также представляет интерес для понимания сущности института "старших эмиров", т.к. хорошо известно, что его род происходил из султанских гулямов ${ }^{96}$, а не из родовой огузской аристократии.

4. Объявление султаном Изз ад-Дином джихада против татар и назначение одного из “старших эмиров" на должность командующего войсками ${ }^{97}$.

${ }^{91}$ Baybars al-Mansūrī, Zubdat al-Fikra fì Ta'rīch al-Hijra, Berlin-Beirut, 1998, ţ2 3 :

92 Unuju untinnux, t, 21:

${ }^{93}$ Unıju untinnuर, 52 50:

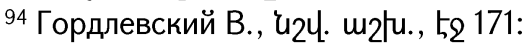

95 Baybars al-Mansūrī, Zubdat al-Fikra fī Ta'rīch al-Hijra, Berlin-Beirut, 1998, стр. 27.

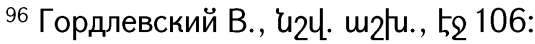

97 Baybars al-Mansūrī, Zubdat al-Fikra fì Ta'rīch al-Hijra, Berlin-Beirut, 1998, 52 31: 
5. Собрание «старших эмиров» и знати войска, которое лишило власти малика ал-Мансура Нур ад-Дина Али и возвело на престол Сайф ад-Дина Кутуза, принявшего тронное имя ал-Мудзафффар ${ }^{98}$.

В тех случаях, когда "старшие эмиры» упоминаются вместе, они решают два вопроса: выбор правителя и ведение войны. В доисламской тюркской политической системе коллективным органом, призванным решать подобные вопросы, являлся курултай (huriltai, hurultai) ${ }^{99}$. Как элемент политической системы кочевников Великой Степи курултай фриксируется с І-го века н.э. (Kuriltai).

Чтобы понять, какие изменения произошли в Египте под влиянием оторванности мамлюков от их родины, разрушения родоплеменных связей и смешения различных тюркских племен и народностей в одной социальной группе необходимо построить модель идеального курултая, наложить ее на египетский материал, зафиксировать отличия и выяснить их причины. Как правило, для построения модели идеального курултая используется монгольский материал XIII века ${ }^{100}$, однако мы нуждаемся в модели, не затронутой установлениями Чингисхана.

Современным мамлюкскому Египту тюркским государством являлся Румский (Сельджукский) султанат. Как уже упоминалось выше, Бейбарс ал-Мансури фриксирует существование собрания «старших эмиров» в этом государстве. Курултай был характерным элементом политической системы Сельджукского султаната ${ }^{101}$. Это собрание должно было проводиться в соответствии с «törü» - сводом неписаных установлений обычного права ${ }^{102}$. Курултай явно имел сакральный характер. Об этом свидетельствует как характер церемонии провозглашения правителя, так и представления тюрок о характере власти государя. Верховный правитель мог избираться только из одного рода (из рода

98 Uny'u untinnux, t. 46:

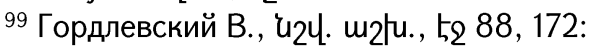

100 Бартольд В. “Сочинения”, т. 2, ч. 1, Общие работы по истории Средней Азии, Москва, 1963, стр. 595-597; Владимирцов Б. "Общественный строй монголов. Монгольский кочевой фреодализм”. Ленинград, 1934, стр. 79.

101 Гордлевский В., 'u24. шаһu., $5_{2} 88,172$ :

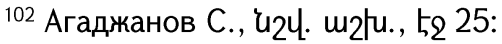


Ашина в Тюркских каганатах $\left.{ }^{103}\right)$, из рода Сельджука в государстве Сельджукидов ${ }^{104}$, что кстати было одной из причин того, что атабеки (за исключением одного случая) не покушались на номинальную верховную власть ${ }^{105}$. Это было связано с определенной функцией государя, который был «первосвященником для народа и для вельмож» ${ }^{106}$, а также был хранителем «törü» ${ }^{107}$. Скрынникова Т.Д., используя, правда, монгольский, но в том числе и дочингизхановский материал, считает, что «актом, с которым были связаны представления о ревитализации и активизации харизмы ${ }^{108}$ и, соответственно, о получении претендентом статуса харизматического правителя, был актом интронизации, который состоялся в сакральной для общности местности.... ${ }^{109}$. На особый статус власти правителя указывают и специальные церемонии, проводившиеся при вступлении на престол нового верховного монарха ${ }^{110}$. Это положение «первосвященника» культа предков обуславливала и особую сакральность родовой территории государя, так как предки рассматривались как заступники и представители перед Небом-Тенгри ${ }^{111}$. Сакральность же самих собраний подчеркивалась и обрядовым пиром, сопровождавшим вступление на престол верховного правителя и обсуждение военных походов, на котором представители племен получали кусок мяса, определенный "тӧре»"112. Участниками курултаев были беи"113, т.е. родоплеменная

103 Гумилев Л. “Древние тюрки”. Санкт-Петербург, 2003, стр. 64-67, 514-517.

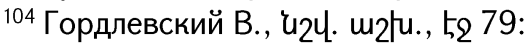

105 Гусейнов Р., 'и2Ч. шиһu., 52 190:

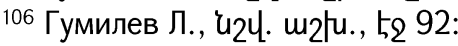

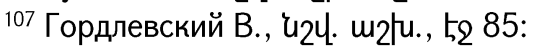

108 sülde.

109 Скрынникова Т. “Сакральность правителя в средневековом монгольском обществе. Сакрализация власти в истории цивилизаций”, ч. II, III, Москва, 2005, стр. 110.

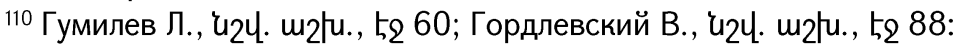

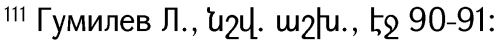

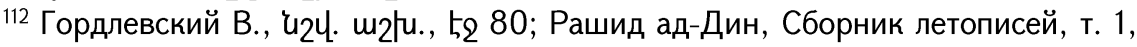
ч. 2, Москва, 2002, стр. 87-91. 
знать ${ }^{114}$ и «старшие беи» ${ }^{115}$, они же «старшие эмиры», т.е. представители неродовой знати.

Исходя из всеговыше сказанного, курултай можно определить как сопровождающееся пиром надплеменное собрание глав этоносоциальных объединений, проводившееся на территории правящего в данной конфедерации племен рода, имеющее сакральный характер, на котором происходило получение или подтверждение особого статуса верховного правителя, решались разнообразные внешнеполитические вопросы (прежде всего организации военного похода) и вводились установления.

Теперь нам необходимо перенести эту схему на ситуацию в мамлюкском Египте по данным «Сливок мысли в истории хиджры».

Необходимо отметить, что в Египте понятие «старший эмир» было наполнено другим содержанием, не связанным с кровнородственными или этнополитическими отношениями. Так как мамлюки поступали в Египет в качестве рабов после монгольских походов 1215-1216, 12191220, 1228-1229гг. ${ }^{116}$, а также после похода 1236-1241гг. ${ }^{117}$, то, естественно, что сохранение родоплеменных структур становилось невозможным. Организация мамлюков пыталась копировать родоплеменные связи через формирование мамлюкских домов - бейтов (bayt - ثيي) основывавшихся на корпоративных связях ${ }^{118}$. Эти связи образовывались путем прикрепления прибывающих в Египет мамлюков к правителю или к определенному эмиру. Указанием на главу "бейта» служила особая нисба, образованная от его имени, а также специальный

113 Гордлевский В., 'น2Ч. ш2łu., $5_{2}$ 88; Рашид ад-Дин, Сборник летописей, т. 1, ч. 2, Москва, 2002, стр. 99.

114 История Востока, в 6 т., т. II. Восток в Средние века. Москва, 2002, стр. 152.

115 Гордлевский В., ч2Ч. шұłu., 52116 :

116 Плетнева С. “Половцы”. Москва, 1990, стр. 170; Буниятов 3., 'и2Ч. шұ2и., 52 197-198; Рашид ад-Дин. “Сборник летописей”, т. 1, ч. 2, Москва, 2002, стр. 177, 226-228.

117 Рашид ад-Дин. “Сборник летописей”, т. 2, ч. 1, Москва, 2002, стр. 37-40.

118 Зеленев Е. “Египет. Средние века. Новое время”, Санкт-Петербург, 1999, стр. 129. 
отличительный знак ${ }^{19}$. Мамлюки продолжали ощущать свою этноплеменную принадлежность (например, первый мамлюкский малик алМуизз Изз ад-Дин Айбек имел нисбу ат-Туркмани, т.е. туркмен ${ }^{120}$, но, конечно же, не могло быть и речи о возрождении кипчакской родоплеменной организации в Египте. Приверженность роду сменяласть приверженностью главе «бейта», то есть командиру подразделения. Родоплеменные связи сменились системой корпоративных связей, в которых главами объединений становились военные предводители - эмиры сотни, сорока, десяти и пяти мамлюков ${ }^{121}$. На войне эмиры сотни командовали, кроме своей сотни, еще и тысячей воинов халка, поэтому мамлюкские историки и называют их «командующими сотни, предводителями тысячи» ${ }^{122}$. Можно предположить, что» старшими эмирами» в мамлюкском Египте назывались главы домов, т.е. эмиры самого старшего подразделения. Эмиры сотни, которых одновременно насчитывалось не более двух-трех десятков, занимали главенствующее положение в мамлюкской иерархии ${ }^{123}$.

Построив модель курултая, необходимо применить ее по отношению к имеющемуся материалу по Египту. Сравнение будет проводиться по трем основным параметрам: место проведения, состав и функции. Результаты могут быть представлены в следующей таблице:

\begin{tabular}{|c|c|c|}
\hline & «Модельный» & Египетский \\
\hline $\begin{array}{l}\text { Место } \\
\text { проведения }\end{array}$ & Священная родовая территория & $\begin{array}{l}\text { В зависимости от } \\
\text { ситуации }\end{array}$ \\
\hline $\begin{array}{l}\text { Состав } \\
\text { участников }\end{array}$ & $\begin{array}{l}\text { Представители правящей } \\
\text { династии, старшие эмиры, эмиры }\end{array}$ & $\begin{array}{l}\text { Старшие эмиры, знать } \\
\text { войска (a'yān al-'askar), } \\
\text { эмиры }\end{array}$ \\
\hline Функции & $\begin{array}{l}\text { Получение или возобновление } \\
\text { статуса верховного правителя; } \\
\text { государственные и военные } \\
\text { вопросы }\end{array}$ & $\begin{array}{l}\text { Избрание малика из } \\
\text { своей среды, } \\
\text { обсуждение военных } \\
\text { вопросов. }\end{array}$ \\
\hline
\end{tabular}

119 Хотко С. “Черкесские мамлюки: краткий исторический очерк”. Майкоп, 1993, стр. 35, 43.

${ }^{120}$ Baybars al-Mansūrī, Zubdat al-Fikra fī Ta'rīch al-Hijra, ţ 6:

${ }^{121}$ Семенова Л. “Салах ад-дин и мамлюки в Египте”. Москва, 1966, стр. 51.

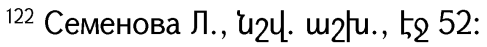

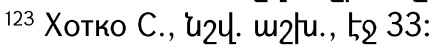


Необходимо отметить, что в условиях исламского общества и оторванности кипчаков-мамлюков от их родовых территорий, курултай не мог сохранить своего сакрального значения. Вопросы, находившиеся в ведении этого собрания в указанную эпоху, входили в компетенцию халифа, который через проведение специальной церемонии, отправку жалованной одежды, знамени, барабана и скипетра ${ }^{124}$, санкционировал приход к власти нового правителя. Объявив себя защитниками ислама ${ }^{125}$, мамлюки не могли сохранять религиозный характер неисламского института. Десакрализация курултая привела к переосмыслению в тюркских исламских государствах этого собрания, которое начинает мыслиться и называться на тюркских языках как пир - نلايث shīlān ${ }^{126}$ или характеризуется описательно («собрались и договорились») $)^{127}$. Возможность принимать установления также была ограничена действием шариата и необходимостью получения феетвы от муфтия. В мамлюкском Египте курултай потерял свой характер надплеменного объединения, а стал, по существу, советом высших военных командиров.

Можно сделать вывод, что в мамлюкском Египте середины XIII века "старшие эмиры» превращаются в военных командиров, которые возглавляют объединения, основанные преимущественно на корпо-

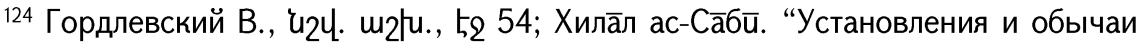
двора халифов”. Москва, 1983, стр. 66; Гусейнов Р. “Султан и халиф (из истории сюзеренитета и вассалитета на Ближнем Востоке XI-XII вв.”., Палестинский сборник, вып. 19 (82), Ленинград, 1969, стр. 130-131; al-Maqrīzī Ahmad ibn 'Alī, Kitāb al-Sulūk li-ma'rifat duwal al-mulūk, mode of access: http://www.al-eman.com/islamlib, 659 p.:

${ }^{125}$ Baybars al-Mansūrī, Zubdat al-Fikra fī Ta'rīch al-Hijra, $t_{2}$ 1:

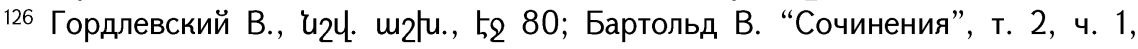
Общие работы по истории Средней Азии. Москва, 1963, стр. 162-163.

${ }^{127}$ al-Maqrīzì Ahmad ibn 'Alī, Kitāb al-Sulūk li-ma'rifat duwal al-mulūk, mode of access: http://www.al-eman.com/islamlib, 650 p.: Ibn Taghrïbirdī. Al-Nujūm alzāhira fī mulūk Mişr wa al-Qāhira, mode of access: http://www.aleman.com/islamlib. 
ративных связях, а их совет (курултай в тюркоязычной терминологии) характеризуется следующими особенностями:

1. Само понятие «курултай» начинает размываться и исчезать.

2. Собрание теряет свою сакральность и связь с родовой территорией

3. Фактически, расширяется состав участников: в случае выборов правителя требуется санкция халифра, в случае принятия каких-либо установлений требуется решение улемов и фракихов.

4. Родоплеменной характер состава полностью утрачивается, курултай представляет собой по существу собрание военных командиров.

5. Курултай сохраняет при участии старших эмиров и эмиров свои функции избрания правителя, а также функции военного совета.

Таким образом, женитьба на вдове умершего правителя, принятие титула атабека при малолетнем малике и согласие высших военных командиров стали основными элементами процесса возведения на престол ал-Муизза Изз ад-Дина Айбека. Необходимо посмотреть, какая схема будет использована при восшествии на трон следующих мамлюкских правителей.

После убийства Айбека в 1257г. (655 г.х.), маликом стал его малолетний сын - ал-Мансур Нур ад-Дин Али. Решение о кандидатуре нового правителя было принято на совете эмиров, возглавляемом ближайшим сподвижником погибшего малика Кутузом ${ }^{128}$. Ал-Муизз оставил после себя двух сыновей ${ }^{129}$. Бейбарс ал-Мансури сообщает только возраст Али - «около десяти лет» ${ }^{130}$. О втором же говорится, что «он оделся как факир, и стал жить нищенствованием, пока не закончилась его жизнь» ${ }^{131}$. Можно допустить, что такая судьба ему была уготована только с одной целью - дать возможность Кутузу стать атабеком при малолетнем Нур ад-Дине, сконцентрировав, таким образом, в своих руках всю полноту власти. По сообщению Бейбарса ал-Мансури, Кутуз

\footnotetext{
${ }^{128}$ Baybars al-Mansūrī, Zubdat al-Fikra fī Ta'rīch al-Hijra, ţ2 24:

129 Unuju untinnux:

130 Unıju untinnux, 52 25:

131 uny'u untinnư, t, 24:
} 
достиг своей цели ${ }^{132}$, однако аль-Макризи дает другую информацию: Кутуз стал «заместителем султана - nā’ib al-sulțān» и «устроителем mudabbir» [дел] государства, а атабеком при пятнадцатилетнем Али стал эмир Фарис ад-Дин Актай ${ }^{133}$, который, по версии Бейбарса алМансури, да и самого ал-Макризи был убит еще в 652 г.х. (1254г.) $)^{134}$. Впрочем, воскресение персонажей у последнего встречается нередко: убитый в 648 г.х. (1250) Туран-шах воскресает в 650 г.х. (1252г.), чтобы вернуться в Сирию ${ }^{135}$. К чести Бейбарса ал-Мансури, он сообщает о смерти Туран-шаха только один раз - в 658 г.х. $(1259 / 1260 г г .)^{136}$. И Бейбарс, и ал-Макризи подтверждают, что реально делами государства занимался Кутуз ${ }^{137}$.

Вскоре всемогущий атабек сам возжелал взойти на трон. Толчком к этому послужило, по-видимому, взятие монголами Багдада и выдвижение войск Хулагу к Египту. При свержении в 657 г.х. (1259г.) Нур ад-Дина Али были использованы почти те же средства, что и при низложении ал-Ашрафра Мусы: апелляция к неспособности малолетнего малика защитить страну от врага ${ }^{138}$; должность Кутуза как атабека; согласие эмиров, которые Бейбарсом ал-Мансури были охарактеризованы как старшие ${ }^{139}$.

132 Unıju untinnux, t52 25:

133 al-Maqrīzì Ahmad ibn 'Alī, Kitāb al-Sulūk li-ma'rifat duwal al-mulūk, mode of access: http://www.al-eman.com/islamlib, 655 p.:

${ }^{134}$ Baybars al-Mansūrī, Zubdat al-Fikra fī Ta'rīch al-Hijra, Berlin-Beirut, 1998, p. 25; al-Maqrīzī Ahmad ibn 'Alī, Kitāb al-Sulūk li-ma'rifat duwal al-mulūk, mode of access: http://www.al-eman.com/islamlib, 652 p.:

135 al-Maqrīzì Ahmad ibn 'Alī, Kitāb al-Sulūk li-ma'rifat duwal al-mulūk, mode of access: http://www.al-eman.com/islamlib, 648 p., 650 p.:

${ }^{136}$ Baybars al-Mansūrī, Zubdat al-Fikra fī Ta'rīch al-Hijra, $t_{2}$ 58:

137 Baybars al-Mansūrī, Zubdat al-Fikra fī Ta'rīch al-Hijra, $\$_{2}$ 24-46: al-Maqrīzī Ahmad ibn 'Alī, Kitāb al-Sulūk li-ma'rifat duwal al-mulūk, mode of access: http://www.al-eman.com/islamlib 655-657 pp.:

138 Baybars al-Mansūrī, Zubdat al-Fikra fī Ta'rīch al-Hijra, $\hbar_{2}$ 46: al-Maqrīzī Ahmad ibn 'Alī, Kitāb al-Sulūk li-ma'rifat duwal al-mulūk, mode of access: http://www.aleman.com/islamlib, 657 p.:

139 Baybars al-Mansūrī, Zubdat al-Fikra fī Ta'rīch al-Hijra, Berlin-Beirut, 1998, p. 46; al-Maqrīzì Ahmad ibn 'Alī, Kitāb al-Sulūk li-ma'rifat duwal al-mulūk, mode of 
С именем Кутуза связана довольно любопытная информация, передаваемая ал-Макризи: «Говорят, что его (т.е. Кутуза - А.Ф.) звали Махмуд ибн Мамдуд, что его мать - сестра Джалал ад-Дина Хорезмшаха, а его отец - сын дяди по отцу султана Джалал ад-Дина» ${ }^{140}$. Достоверность этих сведений сомнительна. Секретарь брата предполагаемой матери египетского малика, Джалал ад-Дина Манкбурны, Шихаб ад-Дин ничего не сообщает о Кутузе ${ }^{141}$. 3. М. Буниятов пишет, что Кутуз был сыном Хан-Султан ${ }^{142}$. Однако последняя после разгрома государства Хорезмшахов была выдана за Джучи ${ }^{143}$. Некоторые современные арабские авторы склонны принимать на веру знатное происхождение Кутуза ${ }^{144}$.

Единственную зафиксированную попытку создания фральшивой генеалогии мамлюкского правителя можно объяснить следующим. С падением в 1258г. Багдада и выходом монголов к границам Египта резко сменились приоритеты внешней политики мамлюков. С момента своего прихода к власти мамлюки нуждались в исламской легитимации осуществленного ими переворота ${ }^{145}$. Кратчайший и одновременно самый надежный путь - получение санкции Аббасидского халифа через проведение специальной церемонии облечения властью, предоставления жалованной одежды и знамени. Это позволило бы мамлюкским правителям титуловаться султанами. С Багдадом постоянно велись переговоры по этому вопросу, но к положительному результату они не привели ${ }^{146}$. Уничтожение же халифата лишило мамлюков возможности

access: http://www.al-eman.com/islamlib, 657 p.:

140 al-Maqrīzī Ahmad ibn 'Alī, Kitāb al-Sulūk li-ma'rifat duwal al-mulūk, mode of access: http://www.al-eman.com/islamlib, 658 p.:

141 Буниятов 3. “Комментарии, Шихаб ад-Дин Мухаммад ан-Насави. Жизнеописание султана Джалал ад-Дина Манкбурны”. Баку, 1973.

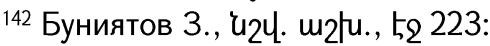

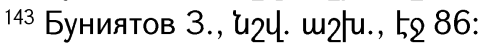

144 Tamām A., Qutuz. Qahara al-mugūl wa ța'anahu al-rifāq, mode of access: http://www.islamonline.net/Arabic/history/1422/01/article30.shtml, 1422 r.x.

145 Филиппов А. "Становление власти Мамлюков в Египте (1252-1260гг.), Египет, Ближний Восток и глобальный мир”. Москва, 2006, стр. 113-115.

146 Филиппов А., 'u24. u2łu., t,2 113-115: 
получить санкцию на свое правление от халифа. Вероятно, именно тогда у египетского малика зародилась идея обосновать свои притязания на престол, породнившись с известной, но уже уничтоженной правящей династией. Что касается Бейбарса ал-Мансури, то он ничего не сообщает о происхождении Кутуза ${ }^{147}$.

Однако правление Кутуза, принявшего лакаб ал-Мудзаффар, было недолгим. После разгрома монголов под Айн-Джалутом группа эмиров, опасавшихся расправы, организовала против малика заговор. На пути в Каир Кутуз был убит ${ }^{148}$.

Заговорщики выбрали новым правителем Рукн ад-Дина Бейбарса ал-Бундукдари, принявшего лакаб аз-Захир. Однако новый малик оказался в весьма сложных условиях: источники ничего не сообщают о женах Кутуза и о попытках Бейбарса вступить с ними в брак; нет информации о детях убитого малика, при которых можно было бы стать атабеком; принадлежа к фракции Фарис ад-Дина Актая ${ }^{149}$, Бейбарс, по-видимому, не мог рассчитывать на согласие "старших эмиров", большиство из которых, особенно после проведенных Кутузом «чисток» ${ }^{150}$, были сторонниками погибшего правителя. По-существу, азЗахир не мог задействовать даже неисламские механизмы легитимации собственной власти, превращаясь в абсолютного узурпатора. Бейбарс был вынужден пойти по другому пути, отличному от того, который выбрали его предшественники.

Выводы:

Механизм смены власти в раннебахритский период носил исключительно тюркский характер, то есть был значимым только внутри

147 Baybars al-Mansūrī, Zubdat al-Fikra fī Ta'rīch al-Hijra, Berlin-Beirut, 1998.

148 Baybars al-Mansūrī, Zubdat al-Fikra fī Ta'rīch al-Hijra, 52 53-54: al-Maqrīzī Ahmad ibn 'Alī, Kitāb al-Sulūk li-ma'rifat duwal al-mulūk, mode of access: http://www.al-eman.com/islamlib, 658 p.:

${ }^{149}$ Baybars al-Mansūrī, Zubdat al-Fikra fị Ta'rīch al-Hijra, $\hbar_{2}$ 12: al-Maqrīzī Ahmad ibn 'Alī, Kitāb al-Sulūk li-ma'rifat duwal al-mulūk, mode of access: http://www.aleman.com/islamlib, 658 p.:

150 Baybars al-Mansūrī, Zubdat al-Fikra fī Ta'rīch al-Hijra, ț2 46: al-Maqrīzī Ahmad ibn 'Alī, Kitāb al-Sulūk li-ma'rifat duwal al-mulūk, mode of access: http://www.aleman.com/islamlib, 657 t.2: 
правящей мамлюкской элиты.

Сам этот механизм сочетал в себе две группы элементов: вхождение в правящий род и получение согласия правящей элиты, то есть, исходя из специфики устройства тюрских государств, он должен был обеспечить получение родовой и политической легитимации.

Вхождение в правящий род обеспечивалось браком с супругой бывшего правителя, на краткий период возведенной на трон, и занятие должности атабека (“князя-отца») при малолетнем государе. Кроме того, этот пост стал средством сосредоточения в руках атабека всей полноты власти.

К элементу политической легитимации следует отнести «совет старших эмиров», видоизмененный курултай, который в мамлюкском Египте принял вид совета высших военных командиров.

Захвативший в 1260г. власть малик аз-Захир Бейбарс, в силу обстоятельств не мог использовать механизм тюркской легитимации своей власти и был вынужден обратиться к исламскому - к восстановлению Халифата.

\section{\$hLhTกบ ULteUUน?}

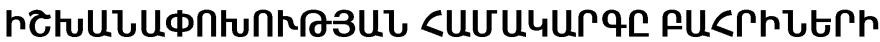

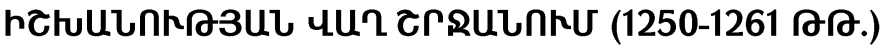

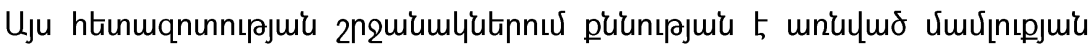

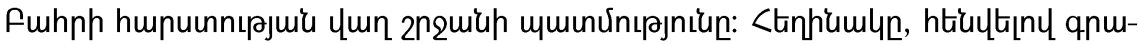

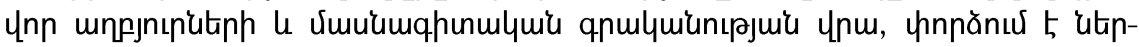

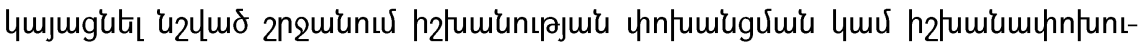

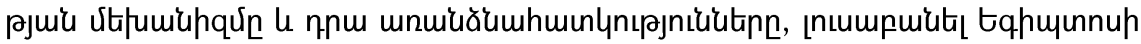

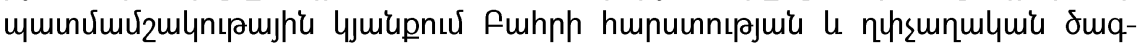

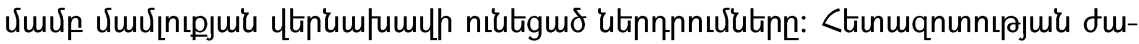

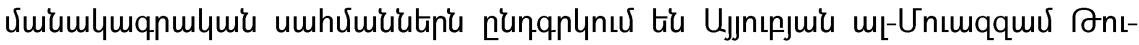

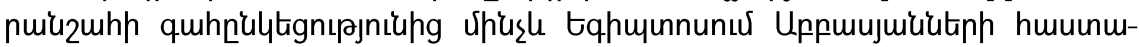

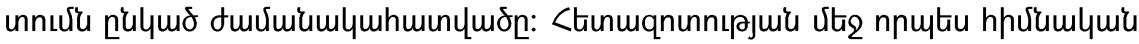

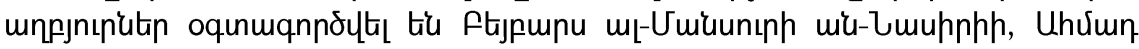

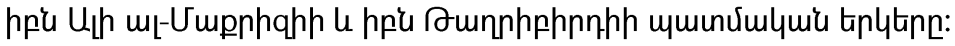

